\title{
Effect of probiotic Bifidobacterium animalis as an alternative to growth-promoting antibiotics on performance, egg quality, and health parameters in young laying hens
}

\section{Balcón-Pacheco Cristina D.}

Posgrado en Maestría Interinstitucional en Producción Pecuaria. División de Ciencias de la Vida, Campus IrapuatoSalamanca, Universidad de Guanajuato, México

\section{Coronel-Gómez Fabiola D.}

Posgrado en Maestría Interinstitucional en Producción Pecuaria. División de Ciencias de la Vida, Campus IrapuatoSalamanca, Universidad de Guanajuato, México

\section{Ozuna César}

Universidad de Guanajuato Division de Ciencias de la Vida

\section{Jiménez-Fernández Maribel}

Universidad Veracruzana

\section{Angel-Sahagún César}

Universidad de Guanajuato Division de Ciencias de la Vida

Elena Franco Franco Robles ( $\nabla$ e.franco@ugto.mx )

Universidad de Guanajuato Division de Ciencias de la Vida https://orcid.org/0000-0003-0345-7578

\section{Research Article}

Keywords: early phase laying, probiotics, egg, leucocytes

Posted Date: February 10th, 2022

DOI: https://doi.org/10.21203/rs.3.rs-1204725/v1

License: (c) (i) This work is licensed under a Creative Commons Attribution 4.0 International License. Read Full License 


\section{Abstract}

Probiotics are live microorganisms that promote the selective growth of beneficial bacteria in birds and can be an effective alternative to growth-promoting antibiotics (GPAs) in poultry. The present study was conducted to determine the effects of dietary probiotics in the diet of early phase laying hens on laying performance, egg quality, blood parameters, and organs morphological characteristics. Seventy-two 13-week-old Lohman White hens were randomized into three dietary groups feed diets with GPA ( $0.5 \%$ of COLI-ZIN), probiotic (PRO; $0.1 \%$ Bifidobacterium animalis ssp lactis) or without additive (control; $C O N$ ) for a 90-days feeding trial. Significant differences were observed in feed intake and feed conversion ratio in PRO with respect to GPA and CON at 90-days treatment $(p<0.05)$. PRO-treated group improved egg weight compared with the GPA and CON groups, but with no statistically significant difference. The air cell height, yolk volume, and yellowness of yolk color were lower, and thick and thin albumen were greatest in PRO than CON and GPA groups $(p<0.05)$. Dietary PRO decreased the number of heterophils and increased the number of lymphocytes, improving the $\mathrm{H} / \mathrm{L}$ index significantly $(\mathrm{p}<0.05)$. PRO treatment increases the relative weight of crop and duodenum compared to GPA $(p<0.05)$. No significant changes in the relative weight of reproductive organs were observed. Based on the results of the present study, it can be concluded that, Bifidobacterium animalis ssp lactis supplementation can be used as a safe alternative in young laying hens.

\section{Introduction}

Due to the high demand in poultry production, growth-promoting antibiotics (GPAs) are usually used to improve feed conversion, reduce mortality of production birds, accelerate their development and production, increase weight gain (Suresh et al. 2018; Muhammad et al. 2020). Since the prohibition of GPAs in 2006 in the European Union due to the emergence of bacterial resistance and that have been found as residues in tissues and products such as milk, eggs, and meat, other countries such as Japan, the United States, and Canada have joined the initiative establishing guidelines for the prohibition of the use of GPA. Moreover, South Korea, New Zealand, and Mexico and others, have reduced its use (McNamee et al. 2013; Mund et al. 2017; Vieco-Saiz et al. 2019).

In this regard, one of the most recommended alternatives that can contribute to reducing bacterial resistance to antimicrobials is the use of probiotics. Probiotics are known as living microorganisms that provide substantial benefits to the health of the host, after their administration in optimal and safe amounts. There is a wide variety of strains, the most used are Lactobacillus, Enterococcus, Pediococcus, Bacillus, or Bifidobacterium alone or in combination and administered in powder form dissolved in water or incorporated into food (Forte et al. 2016; Alagawany et al. 2018; Yan et al. 2019).

It has been shown that the addition of probiotics in the early stages of poultry growth shows a very useful effect on the constitution of the intestinal microbiota and therefore in the laying stage (Kabir, 2009; Hassanein \& Soliman, 2010). The mechanism by which probiotics act in poultry is not yet very clear; however, it has been postulated that it is due to the stimulation of the selective growth of beneficial bacteria that increase short-chain fatty acids like propionate which is a precursor of gluconeogenesis, increase the availability of glucose; maturation, maintenance, and prevention of intestinal integrity reducing the probability of inflammation; modulation of the immune system by neutralization of enterotoxins, and improvement of digestion and metabolism due to the activity of bacterial strains (Kabir, 2009; Lan et al. 2016; Peng et al. 2016). Therefore, the aim of this study was to evaluate the productive performance, egg quality, and health status of laying hens treated with Bifidobacterium animalis ssp lactis compared with the effect of the use of a growth-promoting antibiotic (Colizin) and without.

\section{Material And Methods}




\section{Animals, management, and experimental diets}

The protocol of bird experiments was approved by the Institutional Committee of Bioethics in Research of the University of Guanajuato (CIBIUG-P36-2020), Guanajuato, Mexico. A total of 72 hens of the 13-week-old Lohmann White strain were purchased from a local commercial layer farm (Jalisco, Mexico). All birds were divided into wire cages $\left(25 \mathrm{~cm} \times 35 \mathrm{~cm} \times 40 \mathrm{~cm}\right.$ ) with a floor slope of $12^{\circ}$ and individual feed trough and water trough and were housed under controlled environmental conditions with a room temperature keep at $25-27^{\circ} \mathrm{C}$ with exposure to 6 hours continuous artificial lighting and 8 hours darkness. The birds were fed with a balanced diet for 2 weeks previous weeks of adaptation and during for 90-days experimental period. The diet was formulated based on the nutritional requirements of laying hens (LOHMANN LSL CLASSIC Management guide, 2020). Table 1 presents the ingredients and the composition of the diets. The laying hens were randomly assigned into three dietary treatment groups with 24 birds in each group. The diets were supplemented with $0.5 \%$ of COLI-ZIN (zinc bacitracin and colistin sulfate) as a growthpromoting antibiotic (GPA) and $0.1 \%$ of Bifidobacterium animalis ssp lactis as probiotic (PRO), or without (control; $\mathrm{CON})$. The Bifidobacterium animalis ssp lactis strain showed the viability of $3 \times 10^{11} / \mathrm{g}\left(\mathrm{Bi}-07300 \mathrm{~B}\right.$, FloraFIT ${ }^{\circ}$, Danisco, USA) (figure 1).

\section{[TABLE 1]}

\section{[FIGURE 1]}

Figure 1. Scanning electron microscopy micrographs of the Bifidobacterium animalis sub. Lactis.

\section{Sample collection and laying performance}

All birds were weighed once a week throughout the experimental phase. Feed intakes were recorded daily, and egg production was recorded at three times $(30,60$, and 90 days) of the feeding period. The eggs were collected daily twice at 8:00 a.m. and 3:00 p.m. and weighed. Egg production was calculated by the number of eggs produced daily divided by the number of hens. The feed conversion ratio (FCR) was calculated by dividing kilograms of feed per kilograms of egg (Tapingkae et al. 2017).

\section{Egg quality parameters}

Egg quality was evaluated at the end of the experiment at 26 weeks of animal age. A total of 36 eggs were collected (12 eggs for each treatment) to determine egg quality parameters. Egg width, egg length, shell thickness, air cell height, thick albumen, thin albumen, albumen height, yolk height, yolk length, and total diameter were measured using a digital caliper (model HER-411, Steren, Mexico) and expressed as mm, and shape index (\%) was calculated (Abanikannda et al. 2007; Hanusová et al. 2015). Egg surface was calculated using the formula: $E S\left(\mathrm{~cm}^{2}\right)=4.68 \mathrm{~W}^{2 / 3} ;$ were: W= egg weight (Sauveur, 1988). Yolk volume, Improved Albumen Index (Ali) used as an alternative to Haugh units, and Egg Quality Index (EQI) was determined by Narushin et al. 2021. Egg yolk color was determined by the color profile L* (lightness value), a* (redness value), b* (yellowness value) using Hunterlab Colour Flex (Hunterlab, USA).

\section{Sampling and heterophile and lymphocyte index}

Ten animals per treatment were selected for the blood collection, which was based on the technical bulletin for the appropriate one for the strain used. Briefly, blood was collected from the alar vein with a 22-gauge needle in heparinized tubes (BD Vacutainer®), after $12 \mathrm{~h}$ fasting. To the total count of leukocytes were used a Neubauer chamber diluting the sample 1:20 in Natt and Herrick solution (Natt \& Herrick, 1952). Then, the nine quadrants of the entire chamber were counted (40X) and multiplied by 20 and divided by 1000, reporting the number of leukocytes $\mathrm{x}$ 
$10^{3} / \mu \mathrm{L}$ (Acevedo et al. 2012). To perform leukocyte differential counts we used the Wright stain. To calculate the $\mathrm{H}: \mathrm{L}$ index, which is a direct indicator of animal stress, we divide the number of heterophils by the number of lymphocytes (Gross \& Siegel, 1983).

\section{Determination of weight and $\mathrm{pH}$ of various organs}

At the end of the experiment, ten hens of each treatment were weighed and slaughtered according to guidelines of NOM-033-ZOO-1995, Mexico. Crop, proventriculus, gizzard, duodenum, jejunum, ileum, large intestine, ceca, heart, liver, spleen, kidney, lung, brain, ovary, infundibulum, magnum, isthmus, uterus, and vagina were immediately removed and weighed. The data are expressed in \% of body mass. Finally, the determination of the pH (model Hi98103, Hanna, USA) of major organs was performed.

\section{Statistical Analysis}

Data were analyzed by one-way ANOVA using Statistica software (version 8.0, Statsoft, USA). The analysis of the comparison between means was performed using Duncan's multiple range test considering a $\mathrm{p} \leq 0.05$ as significant.

\section{Results}

\section{Laying hen performance and egg quality}

Table 2 shows the effect of CON and GPA and PRO treatments on the performance of the laying hens three times (30, 60 , and 90 days) during 13 to 26 weeks of age. No significant differences were observed in feed intake between treatments in two first times in response to the different functional ingredients. However, in the last period, PRO treatment decreases significantly feed intake compared to GPA and CON groups $(p<0.001)$. On the other hand, no significant differences were observed hen-day egg production and egg weight between treatments during three experimental periods. Interestingly, PRO treatment decreases significantly feed conversion ratio compared to GPA and CON groups in the third period $(p<0.001)$.

\section{[TABLE 2]}

\section{Egg quality}

Table 3 presents the effects of quality parameters of eggs collected at the end of the experimental period ( 13 weeks). No significant differences were observed in width, length, surface, EQI, shape index, or shell thickness of eggs between treatments. However, the air cell height was lower in PRO treatment compared to GPA treatment and CON groups $(p<0.05)$. Moreover, the thick and thin albumen were greatest in PRO than CON and GPA treatment $(p<0.05)$. Furthermore, we observed that PRO treatment significantly decreases yolk volume with respect to CON and GPA groups $(p<0.05)$. The yellowness of the yolk color was lower in PRO compared to CON groups $(p<0.05)$.

\section{[TABLE 3]}

\section{Leucocyte count}

Figure 2 showed the number of total leucocytes, percent of heterophils and lymphocytes, and H/L index of laying hens at 26 weeks of age. No statistically significant change was observed in a total leucocytes count. However, the number of heterophils was significantly lower in PRO compared to GPA treatment and CON $(p<0.05)$. Conversely, the number of 
lymphocytes was significantly increasing in PRO compared to GPA and CON groups $(p<0.05)$. Therefore, we can observe that the $\mathrm{H} / \mathrm{L}$ ratio decreased significantly with respect to GPA and CON groups $(p<0.05)$.

\section{[FIGURE 2]}

Figure 2. Effects of dietary treatments on total WBC count, heterophile $(H)$, lymphocyte $(L)$, and heterophile/lymphocyte ratio $(H / L)$ of laying hens at 90 days of the experimental period.

\section{Weight and $\mathrm{pH}$ of various organs}

Table 4 presents the weight and $\mathrm{pH}$ of the gastrointestinal tract and visceral and reproductive organs in hens at 26 weeks of age. Regarding the gastrointestinal tract, the PRO treatment increases relative weight and modified the pH levels in the crop compared to the GPA treatment but not to CON $(p<0.05)$. Interestingly, the relative weight of the gizzard is modified by GPA and PRO treatments compared to CON $(p<0.05)$. Moreover, GPA treatment significantly reduces the relative weight of the duodenum compared to PRO treatment and CON $(p<0.05)$. Conversely, PRO treatment significantly increases the relative weight of the large intestine compared to GPA treatment and CON $(p<0.05)$. On the other hand, no statistically significant change was observed in relative weight in visceral organs. Regarding reproductive organs, PRO treatment modified $\mathrm{pH}$ levels in the infundibulum and magnum compared to the CON group $(p<0.05)$. Finally, no significant changes in the relative weight of these organs were observed due to the effect of the treatments.

[TABLE 4]

\section{Discussion}

Functional ingredients have been studied in recent decades as feed additives in the diet of laying hens to replace growth-promoting antibiotics. These include antioxidants, probiotics, prebiotics, herbal extracts, and oils that can affect laying performance and egg quality; however, few studies have evaluated probiotic strains in the performance of laying hens (Hajiaghapour \& Rezaeipour, 2018; Jha et al. 2020). In this study, the inclusion of $0.1 \%$ of $B$. animalis improved the feed conversion ratio while the feed intake was decreases compared to the antibiotics and control diets in the last period in early laying hens. According to our results, Mikulski et al. (2012), showed that a dietary probiotic Pediococcus acidilactici strain at doses of $100 \mathrm{mg} / \mathrm{kg}$ feed at $222 \mathrm{Hy}$-Line Brown laying hens improved the feed efficiency ratio per kilogram of eggs. Conversely, Forte et al. (2016) found that 0.5\% Lactobacillus acidophilus and $1 \%$ Bacillus subtilis as additives to the diet of $900 \mathrm{Hy}$ line White hens for 20 weeks, no significant effect on productive parameters, only the color of the yolk showed significant differences. Moreover, Yan et al. (2019), reported that a commercial mixture of probiotics which contained (Enterococcus faecium, Pediococcus acidilactici, Bifidobacterium animalis and Lactobacillus reuteri) with an inclusion level of $0,0.5,1.0$, and $2.0 \mathrm{~g} / \mathrm{kg}$ for 7 weeks at 60 -week-old White Leghorn hens decreases the percentage of broken eggs but other performance parameters did not show relevant changes.

Concerning egg quality, in the present study, PRO treatment decrease air cell height, yolk volume, and yellowness of yolk color, and improved the thick and thin albumen with respect to GPA and CON in the early stage of laying. However, no modified egg and shell parameters. In this regard, it has been reported that in younger laying hens, the efficiency in absorbing $\mathrm{Ca}$ is less, therefore some parameters of egg quality do not improve (Abdelqader et al. 2013).

To analyze the health status of the hens during supplementation with $B$. animalis we determined the hematological parameters. It has been suggested that dietary bioactive components have immunomodulatory potential which can prevent or mitigate diseases infections in poultry (Kogut 2009). We found that $0.1 \%$ B. animalis increases the percentage of lymphocytes (\%L) and decrease the percentage of heterophils (\%), which participate in acute 
inflammation and phagocytosis of pathogens respectively, and the $\mathrm{H}$ : $\mathrm{L}$ ratio, which is an indicator of animal stress (Gross \& Siegel 1983). Coinciding with our results, the study of Tang et al. (2017), found that dietary supplementation of a probiotic PrimaLac $®$ in the diet of 20-52 weeks old laying hens increases the $\% \mathrm{~L}$ and decreases the $\% \mathrm{H}$, decreasing accordingly the $\mathrm{H} / \mathrm{L}$ ratio. This suggests that probiotics are actively involved in immunological processes, even in healthy animals.

On the other hand, in this study, we observed a significant change in the relative weight of crop, gizzard, duodenum, and large intestine of hens with the inclusion of the probiotic. Numerous studies indicate that the inclusion of probiotics in birds modifies the intestinal microbiota and intestinal histomorphology, through the stimulation of the production of SCFAs (Awad et al. 2009; Song et al. 2014; Ricke 2015; Ricke et al. 2020). Additionally, we observed that the inclusion of GPA decreases the relative weight of the cecum which may be related to the modification of the cecal microbiota (Danzeisen et al. 2011). The results showed that the addition of probiotics does not have a significant effect on visceral organs and reproductive organs. Although in the latter, the $\mathrm{pH}$ of the infundibulum and isthmus was slightly modified, perhaps due to the indirect effect on the modulation of the gastrointestinal microbiota. Probiotics have been reported to have the potential to prevent injury to the reproductive organs of laying hens, as they show antimicrobial and anti-inflammatory effects (Shini et al. 2013), although the mechanisms of probiotics in the reproductive system of laying hens remain unclear.

\section{Conclusion}

It could be concluded that Bifidobacterium animalis ssp lactis at $0.1 \%$ can be used as a dietary additive in the diets of early-stage laying hens without the inclusion of growth-promoting antibiotics. This treatment can improve the quality characteristics of the egg and have an immunomodulatory effect in laying hens decreases physiological stress; therefore, it can be considered a good additive for the diets of early laying hens without negative effects on organs.

\section{Declarations}

\section{Acknowledgements}

Balcón-Pacheco Cristina D., thanks CONACYT for the scholarship no. 907241 for their postgraduate studies.

We thank Biol. Greta Hanako Rosas Saito for the support provided for the micrographs taken in SEM and Mieles Campos Azules, S. A. company from Amatitán Jalisco for providing probiotic treatment and Educational Program in Master in Livestock Production of Universidad de Guanajuato. Project carried out by Elena Franco-Robles and Maribel Jiménez-Fernández, members of the Mexican Thematic network Sustainable integral use and biotechnology of agaves (AGARED) CONACYT, Mexico.

\section{Compliance with ethical standards}

\section{Conflict of interest}

The authors have no competing interests to declare that are relevant to the content of this article.

\section{Ethical standards}

The authors confirm that the ethical policies of the journal, as noted on the journal's author guidelines page, have been adhered to and the appropriate ethical review committee approval has been received. The protocol of bird experiments was approved by the Institutional Committee of Bioethics in Research of the University of Guanajuato (CIBIUG-P36- 
2020). The authors confirm that they have followed Mexican standards for the protection of animals used for scientific purposes (NOM-033-Z00-1995; NOM-062-Z00-1999).

\section{Authors's contribution}

Elena Franco-Robles conceptualization, supervision, writing - review and editing. Cristina D. Balcón-Pacheco and Fabiola D. Coronel-Gómez methodology, analysis, performed the experiment. César Ozuna, Maribel Jiménez-Fernández and César Angel-Sahagún reviewed and criticised the draft manuscript.

\section{Data availability}

Data available on request from the corresponding author.

\section{Declaration of funding}

This research did not receive any specific funding.

\section{References}

1. Abanikannda, O. T. F., Olutogun, O., Leigh, A. O., \& Ajayi, L. A. 2007. Statistical modeling of egg weight and egg dimensions in commercial layers. International Journal of Poultry Science, 6(1), 59-63.

2. Abdelqader, A., Al-Fataftah, A. R., \& Daş, G. 2013. Effects of dietary Bacillus subtilis and inulin supplementation on performance, eggshell quality, intestinal morphology and microflora composition of laying hens in the late phase of production. Animal Feed Science and Technology, 179(1-4), 103-111.

3. Acevedo, L. M. R., Blas, S. S. M., \& Fuentes-Mascorro, G. 2012. Hemograma y características morfológicas de las células sanguíneas de tortuga golfina (Lepidochelys olivacea) de oaxaca, México. Revista Científica, 22(5), 468476.

4. Alagawany, M., Abd El-Hack, M. E., Farag, M. R., Sachan, S., Karthik, K., \& Dhama, K. 2018. The use of probiotics as eco-friendly alternatives for antibiotics in poultry nutrition. Environmental Science and Pollution Research, 25(11), 10611-10618.

5. Awad, W. A., Ghareeb, K., Abdel-Raheem, S., \& Böhm, J. 2009. Effects of dietary inclusion of probiotic and synbiotic on growth performance, organ weights, and intestinal histomorphology of broiler chickens. Poultry science, 88(1), 49-56.

6. Danzeisen, J. L., Kim, H. B., Isaacson, R. E., Tu, Z. J., \& Johnson, T. J. 2011. Modulations of the chicken cecal microbiome and metagenome in response to anticoccidial and growth promoter treatment. PloS one, 6(11), e27949.

7. Forte, C., Moscati, L., Acuti, G., Mugnai, C., Franciosini, M. P., Costarelli, S., ... \& Trabalza-Marinucci, M. 2016. Effects of dietary Lactobacillus acidophilus and Bacillus subtilis on laying performance, egg quality, blood biochemistry and immune response of organic laying hens. Journal of Animal Physiology and Animal Nutrition, 100(5), 977987.

8. Gross, W. B., \& Siegel, H. S. 1983. Evaluation of the heterophil/lymphocyte ratio as a measure of stress in chickens. Avian diseases, 972-979.

9. Hajiaghapour, M., \& Rezaeipour, V. 2018. Comparison of two herbal essential oils, probiotic, and mannanoligosaccharides on egg production, hatchability, serum metabolites, intestinal morphology, and microbiota activity of quail breeders. Livestock Science, 210, 93-98. 
10. Hanusová, E., Hrnčár, C., Hanus, A., \& Oravcová, M. 2015. Effect of breed on some parameters of egg quality in laying hens. Acta fytotechnica et zootechnica, 18(1), 20-24.

11. Hassanein, S. M., \& Soliman, N. K. 2010. Effect of probiotic (Saccharomyces cerevisiae) adding to diets on intestinal microflora and performance of Hy-Line layers hens. J. Am. Sci, 6(11), 159-169.

12. Jha, R., Das, R., Oak, S., \& Mishra, P. 2020. Probiotics (direct-fed microbials) in poultry nutrition and their effects on nutrient utilization, growth and laying performance, and gut health: a systematic review. Animals, 10(10), 1863.

13. Kabir, S. M. 2009. The role of probiotics in the poultry industry. International Journal of Molecular Sciences, 10(8), 3531-3546.

14. Kogut, M. H. 2009. Impact of nutrition on the innate immune response to infection in poultry. Journal of applied poultry research, 18(1), 111-124.

15. Lan, R. X., Lee, S. I., \& Kim, I. H. 2016. Effects of multistrain probiotics on growth performance, nutrient digestibility, blood profiles, faecal microbial shedding, faecal score and noxious gas emission in weaning pigs. Journal of Animal Physiology and Animal Nutrition, 100(6), 1130-1138.

16. McNamee, S. E., Cunningham, R., \& Elliott, C. T. 2013. Simultaneous immunochemical detection of four banned antibiotic growth promoters in raw and cooked poultry tissue. Food Additives \& Contaminants: Part A, 30(7), 1270-1278.

17. Mikulski, D. 1., Jankowski, J., Naczmanski, J., Mikulska, M., \& Demey, V. 2012. Effects of dietary probiotic (Pediococcus acidilactici) supplementation on performance, nutrient digestibility, egg traits, egg yolk cholesterol, and fatty acid profile in laying hens. Poultry science, 91(10), 2691-2700.

18. Muhammad, J., Khan, S., Su, J. Q., Hesham, A. E. L., Ditta, A., Nawab, J., \& Ali, A. 2020. Antibiotics in poultry manure and their associated health issues: a systematic review. Journal of Soils and Sediments, 20(1), 486-497.

19. Mund, M. D., Khan, U. H., Tahir, U., Mustafa, B. E., \& Fayyaz, A. 2017. Antimicrobial drug residues in poultry products and implications on public health: A review. International Journal of Food Properties, 20(7), 1433-1446.

20. Narushin, V. G., Romanov, M. N., \& Griffin, D. K. 2021. A novel Egg Quality Index as an alternative to Haugh unit score. Journal of Food Engineering, 289, 110176.

21. Natt, M. P., \& Herrick, C. A. 1952. A new blood diluent for counting the erythrocytes and leucocytes of the chicken. Poultry Science, 31(4), 735-738.

22. Peng, Q., Zeng, X. F., Zhu, J. L., Wang, S., Liu, X. T., Hou, C. L., ... Qiao, S. Y. 2016. Effects of dietary Lactobacillus plantarum B1 on growth performance, intestinal microbiota, and short chain fatty acid profiles in broiler chickens. Poultry science, 95(4), 893-900.

23. Ricke, S. C. 2015. Potential of fructooligosaccharide prebiotics in alternative and nonconventional poultry production systems. Poultry Science, 94(6), 1411-1418.

24. Ricke, S. C., Lee, S. I., Kim, S. A., Park, S. H., \& Shi, Z. 2020. Prebiotics and the poultry gastrointestinal tract microbiome. Poultry science, 99(2), 670-677.

25. Sauveur B. 1988. Reproduction des volailles et production d'oeufs. Quae. Institut National de la Recherche Agronomique, Paris, France.

26. Shini, S., Shini, A., \& Blackall, P. J. 2013. The potential for probiotics to prevent reproductive tract lesions in freerange laying hens. Animal Production Science, 53(12), 1298-1308.

27. Song, J., Xiao, K., Ke, Y. L., Jiao, L. F., Hu, C. H., Diao, Q. Y., ... \& Zou, X. T. 2014. Effect of a probiotic mixture on intestinal microflora, morphology, and barrier integrity of broilers subjected to heat stress. Poultry science, 93(3), $581-588$. 
28. Suresh, G., Das, R. K., Kaur Brar, S., Rouissi, T., Avalos Ramirez, A., Chorfi, Y., \& Godbout, S. 2018. Alternatives to antibiotics in poultry feed: molecular perspectives. Critical reviews in microbiology, 44(3), 318-335.

29. Tang, S. G. H., Sieo, C. C., Ramasamy, K., Saad, W. Z., Wong, H. K., \& Ho, Y. W. 2017. Performance, biochemical and haematological responses, and relative organ weights of laying hens fed diets supplemented with prebiotic, probiotic and synbiotic. BMC veterinary research, 13(1), 1-12.

30. Tapingkae, W., Panyachai, K., Yachai, M., \& Doan, H. V. 2018. Effects of dietary red yeast (Sporidiobolus pararoseus) on production performance and egg quality of laying hens. Journal of animal physiology and animal nutrition, 102(1), e337-e344.

31. Vieco-Saiz, N., Belguesmia, Y., Raspoet, R., Auclair, E., Gancel, F., Kempf, I., \& Drider, D. 2019. Benefits and inputs from lactic acid bacteria and their bacteriocins as alternatives to antibiotic growth promoters during food-animal production. Frontiers in microbiology, 10, 57.

32. Yan, F. F., Murugesan, G. R., \& Cheng, H. W. 2019. Effects of probiotic supplementation on performance traits, bone mineralization, cecal microbial composition, cytokines and corticosterone in laying hens. Animal, 13(1), 33-41.

\section{Tables}


Table 1. Ingredients and nutritional composition of the experimental diets

\begin{tabular}{|c|c|c|c|}
\hline \multirow[b]{2}{*}{ Ingredients (\%) } & \multicolumn{3}{|c|}{ Treatments } \\
\hline & CON & AGP & PRO \\
\hline Sorghum grain & 37.5 & 37.3 & 37.2 \\
\hline Soya bean meal & 20.4 & 20.4 & 20.4 \\
\hline Corn & 28.5 & 28.5 & 28.7 \\
\hline Fish flour & 10.4 & 10.4 & 10.4 \\
\hline Soya bean oil & 1.1 & 1.1 & 1.1 \\
\hline Calcium carbonate & 1.5 & 1.5 & 1.5 \\
\hline Orthophosphate & 0.5 & 0.5 & 0.5 \\
\hline Vitamins and minerals premix ${ }^{1}$ & 0.09 & 0.09 & 0.09 \\
\hline L- threonine & 0.05 & 0.05 & 0.05 \\
\hline L- tryptophan & 0.05 & 0.05 & 0.05 \\
\hline Colizin & 0 & 0.2 & 0 \\
\hline Bifidobacterium animalis ssp lactis & 0 & 0 & 0.1 \\
\hline Total: & 100 & 100 & 100 \\
\hline \multicolumn{4}{|l|}{ Calculated analysis } \\
\hline ME (Kcal/kg) & 2900 & 2895 & 2898 \\
\hline Crude protein (\%) & 19.4 & 19.3 & 19.3 \\
\hline Crude fiber (\%) & 6.0 & 6.0 & 6.0 \\
\hline Calcium (\%) & 2.01 & 2.01 & 2.01 \\
\hline Phosphorus (\%) & 0.6 & 0.6 & 0.6 \\
\hline
\end{tabular}

${ }^{1}$.Supplied per kilogram of diet: vitamin A 39,378 IU, vitamin D3 5,358 IU, vitamin B1 $8.17 \mathrm{mg}, \mathrm{B} 221.60 \mathrm{mg}, \mathrm{B} 6$ $16.66 \mathrm{mg}, \mathrm{B} 12108 \mathrm{mcg}$, pantothenic acid $82.5 \mathrm{mg}$, folic acid $5.3 \mathrm{mg}$, copper $36 \mathrm{mg}$, biotin $7 \mathrm{mg}$, selenium $0.75 \mathrm{mg}$, zinc $360 \mathrm{mg}$. 
Table 2. Effects of B. animalis, growth promoter antibiotic and control diet on performance of laying hens during 90 days of treatments.

\begin{tabular}{|c|c|c|c|c|c|c|c|c|c|c|c|c|}
\hline \multirow[t]{2}{*}{ Item } & \multicolumn{4}{|c|}{$0-30$ day } & \multicolumn{4}{|c|}{$30-60$ day } & \multicolumn{4}{|c|}{$60-90$ day } \\
\hline & CON & GPA & PRO & SEM & CON & GPA & PRO & SEM & CON & GPA & PRO & SEM \\
\hline $\begin{array}{l}\text { Feed intake } \\
\text { (g/hen/day) }\end{array}$ & 69.6 & 68.6 & 70.4 & 1.28 & 88.7 & 92.1 & 69.7 & 1.17 & $106.2^{a^{\star \star}}$ & $105.9^{a^{\star \star}}$ & $99.6^{b}$ & 0.74 \\
\hline $\begin{array}{l}\text { Hen-day } \\
\text { egg } \\
\text { production } \\
(\%)\end{array}$ & 34.2 & 36.6 & 31.9 & 1.65 & 48.2 & 50.6 & 43.1 & 2.04 & 65.4 & 63.1 & 58.0 & 2.39 \\
\hline $\begin{array}{l}\text { Egg weight } \\
\text { (g) }\end{array}$ & 52.8 & 52.6 & 53.3 & 0.93 & 58.6 & 57.3 & 58.3 & 0.96 & 61.0 & 61.3 & 62.5 & 0.53 \\
\hline $\begin{array}{l}\text { Feed } \\
\text { conversion } \\
\text { ratio (kg } \\
\text { feed/kg } \\
\text { egg) }\end{array}$ & 1.22 & 1.22 & 1.24 & 0.02 & 1.47 & 1.54 & 1.47 & 0.01 & $1.74^{\mathrm{a} \star}$ & $1.72^{a^{\star \star}}$ & $1.64^{b}$ & 0.0 \\
\hline
\end{tabular}

Data are presented as the mean and their SEM. Superscript letters indicate significant differences between the groups by Duncan's test. ${ }^{*} p<0.05,{ }^{*} p<0.001$. CON: basal diet; GPA: basal diet supplemented with $0.5 \%$ of COLIZIN; PRO: basal diet supplemented with $0.1 \%$ of Bifidobacterium animalis ssp lactis. 
Table 3. Effects of B. animalis, growth promoter antibiotic and control diet on egg quality characteristics of laying hens at the end of experimental period.

\begin{tabular}{llllll}
\hline Items & CON & GPA & PRO & SEM & $p$-value \\
\hline Egg width $(\mathrm{mm})$ & 43.8 & 43.7 & 43.9 & 2.27 & 0.89 \\
\hline Egg length $(\mathrm{mm})$ & 57.6 & 57.8 & 57.6 & 3.94 & 0.10 \\
\hline Egg surface $\left(\mathrm{cm}^{2}\right)$ & 75.5 & 72.7 & 73.6 & 0.42 & 0.50 \\
\hline EQI & 116.3 & 114.1 & 116.3 & 0.83 & 0.48 \\
\hline Shape index $(\%)$ & 76.1 & 75.6 & 76.3 & 0.31 & 0.69 \\
\hline Shell thickness $(\mathrm{mm})$ & 0.30 & 0.35 & 0.32 & 0.01 & 0.28 \\
\hline Air cell height $(\mathrm{mm})$ & $1.5^{\mathrm{a}}$ & $1.6^{\mathrm{a}}$ & $0.9^{\mathrm{b}}$ & 0.14 & $\mathbf{0 . 0 4}$ \\
\hline Thick albumen $(\mathrm{mm})$ & $82.9^{\mathrm{a}}$ & $83.8^{\mathrm{a}}$ & $103.1^{\mathrm{b}}$ & 2.77 & $\mathbf{0 . 0 0 0 3}$ \\
\hline Thin albumen $(\mathrm{mm})$ & $61.1^{\mathrm{a}}$ & $66.3^{\mathrm{a}}$ & $77.8^{\mathrm{b}}$ & 2.28 & $\mathbf{0 . 0 0 2}$ \\
\hline Ali & 0.14 & 0.13 & 0.14 & 0.002 & 0.45 \\
\hline Yolk volume $\left(\mathrm{cm}{ }^{3}\right)$ & $16.6^{\mathrm{a}}$ & $17.4^{\mathrm{a}}$ & $13.7^{\mathrm{b}}$ & 0.56 & $\mathbf{0 . 0 1}$ \\
\hline L & 64.3 & 65.1 & 66.2 & 0.58 & 0.43 \\
\hline a & -0.9 & -0.7 & -1.0 & 0.37 & 0.84 \\
\hline b & $32.1^{\mathrm{a}}$ & $28.6^{\mathrm{ab}}$ & $25.5^{\mathrm{b}}$ & 1.09 & $\mathbf{0 . 0 3}$ \\
\hline
\end{tabular}

Note: Data are presented as the mean and their SEM $(n=6)$. Superscript letters indicate significant differences between the groups by Duncan's test $(p<0.05)$. CON: basal diet; GPA: basal diet supplemented with $0.5 \%$ of COLIZIN; PRO: basal diet supplemented with $0.1 \%$ of Bifidobacterium animalis ssp lactis. EQI: Egg Quality Index. Ali: Improved Albumen Index. 
Table 4. Effects of $B$. animalis, growth promoter antibiotic supplementation and control diet of relative weight and $\mathrm{pH}$ of various organs of the laying hens at 26 weeks age.

Organ

Treatments

$p$ value

CON

GPA

PRO

SEM

\section{Gastrointestinal tract}

\section{Crop}

Index (\% BW)

$0.54^{\mathrm{ab}}$

$0.55^{\mathrm{a}}$

$0.61^{b}$

0.03

0.045

$\mathrm{pH}$

$6.13^{a}$

$5.41^{\mathrm{b}}$

$5.37^{b}$

0.10

0.001

\section{Proventriculus}

Index (\% BW)

0.54

0.55

0.45

0.03

0.420

$\mathrm{pH}$

5.68

5.81

5.48

0.06

0.115

\section{Gizzard}

Index (\% BW)

$1.48^{\mathrm{a}}$

$1.24^{b}$

$1.21^{b}$

0.04

0.028

$\mathrm{pH}$

5.63

5.5

5.3

0.07

0.229

\section{Duodenum}

Index (\% BW)

$1.45^{\mathrm{a}}$

$1.25^{\mathrm{b}}$

$1.46^{\mathrm{a}}$

0.03

0.040

$\mathrm{pH}$

5.92

5.98

5.95

0.03

0.829

Jejunum

Index (\% BW)

1.05

0.87

0.92

0.05

0.343

$\mathrm{pH}$

6.03

6.04

5.83

0.04

0.105

Ileum

Index (\% BW)

0.73

0.63

0.62

0.03

0.442

$\mathrm{pH}$

6.03

6.16

6.05

0.04

0.513

\section{Large intestine}

Index (\%)

$1.16^{a}$

$1.14^{\mathrm{a}}$

$1.42^{b}$

0.04

0.014

$\mathrm{pH}$

6.22

6.34

6.26

0.03

0.455

\section{Ceca}

Index (\% BW)

0.56

0.44

0.53

0.02

0.129

$\mathrm{pH}$

6.52

6.52

6.6

0.03

0.547

\section{Visceral organs}

Index (\% BW)

Heart

0.48

0.51

0.46

0.00

0.164

Liver

2.60

2.60

2.41

0.07

0.518 


\begin{tabular}{llllll}
\hline Spleen & 2.60 & 2.60 & 2.41 & 0.00 & 0.521 \\
\hline Kidney & 0.60 & 0.58 & 0.53 & 0.02 & 0.571 \\
\hline Lung & 0.42 & 0.39 & 0.40 & 0.01 & 0.602 \\
\hline Brain & 0.13 & 0.13 & 0.13 & 0.00 & 0.988 \\
\hline
\end{tabular}

\section{Reproductive organs}

\section{Ovary}

$\begin{array}{llllll}\text { Index (\% BW) } & 2.57 & 3.01 & 2.71 & 0.17 & 0.731 \\ \mathrm{pH} & 6.42 & 6.32 & 6.51 & 0.03 & 0.139\end{array}$

\section{Infundibulum}

\begin{tabular}{llllll} 
Index (\% BW) & 0.14 & 0.16 & 0.12 & 0.01 & 0.398 \\
\hline $\mathrm{pH}$ & $6.35^{\mathrm{a}}$ & $6.45^{\mathrm{ab}}$ & $6.51^{\mathrm{b}}$ & 0.02 & 0.032 \\
\hline Magnum & & & & & 0.276 \\
\hline Index (\% BW) & 1.79 & 1.93 & 2.38 & 0.11 & 0.122 \\
$\mathrm{pH}$ & 6.28 & 6.28 & 6.47 & 0.04 & 0.12
\end{tabular}

\section{Isthmus}

Index (\% BW)

0.41

0.45

0.48

0.01

0.742

$\mathrm{pH}$

$6.12^{\mathrm{a}}$

$6.24^{a b}$

$6.32^{b}$

0.04

0.004

\section{Uterus}

$\begin{array}{llllll}\text { Index (\% BW) } & 1.08 & 1.06 & 0.89 & 0.04 & 0.178 \\ \mathrm{pH} & 6.30 & 6.24 & 6.23 & 0.02 & 0.636\end{array}$

\section{Vagina}

$\begin{array}{llllll}\text { Index (\% BW) } & 0.13 & 0.17 & 0.15 & 0.02 & 0.326 \\ \mathrm{pH} & 6.31 & 6.35 & 6.4 & 0.03 & 0.523\end{array}$

Data are presented as the mean \pm SEM. Index (\%): organ weight/ body weight. Superscript letters indicate significant differences between the groups by Duncan's test $(\mathrm{p}<0.05)$. CON: basal diet $(n=10)$; GPA: basal diet supplemented with $0.5 \%$ of COLI-ZIN $(n=10)$; PRO: basal diet supplemented with $0.1 \%$ of Bifidobacterium animalis ssp lactis $(n=10)$.

\section{Figures}




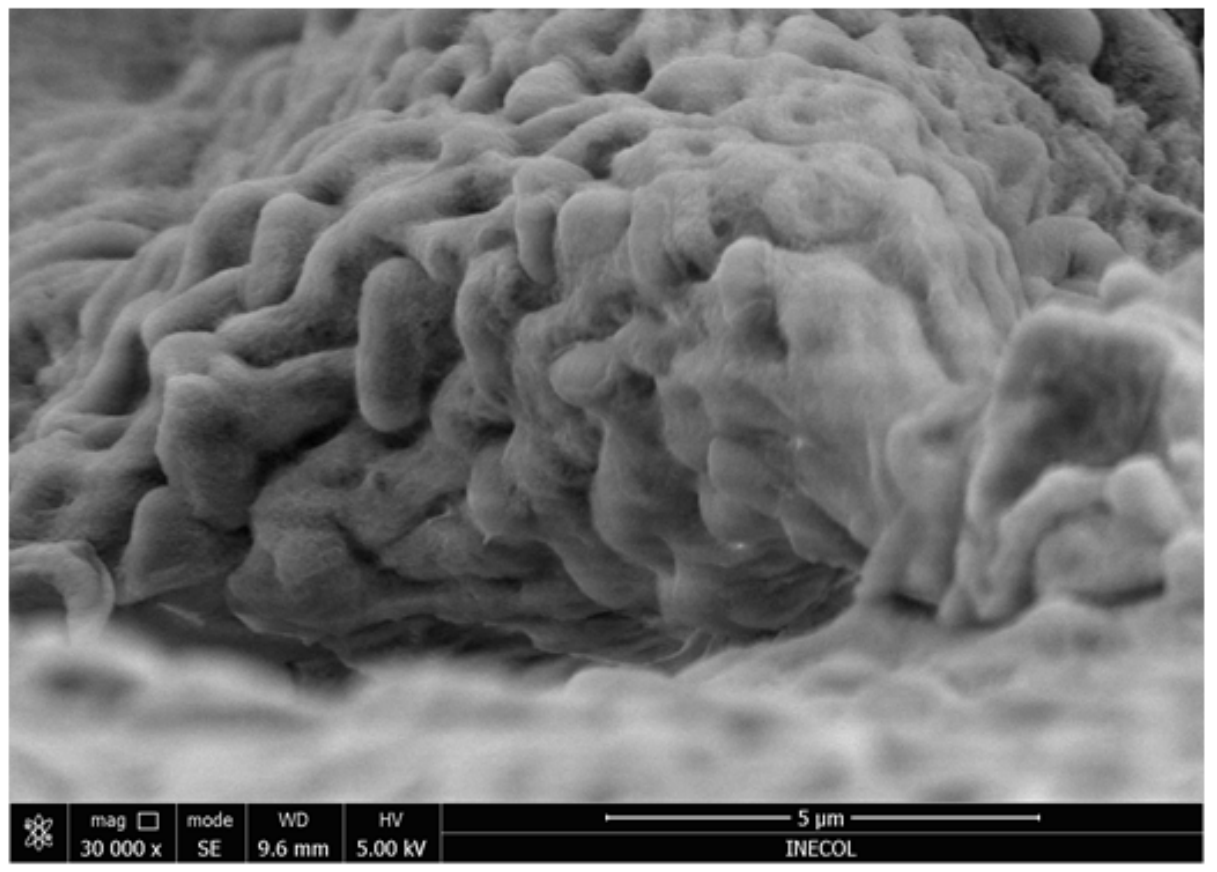

Figure 1

Scanning electron microscopy micrographs of the Bifidobacterium animalis sub. Lactis.

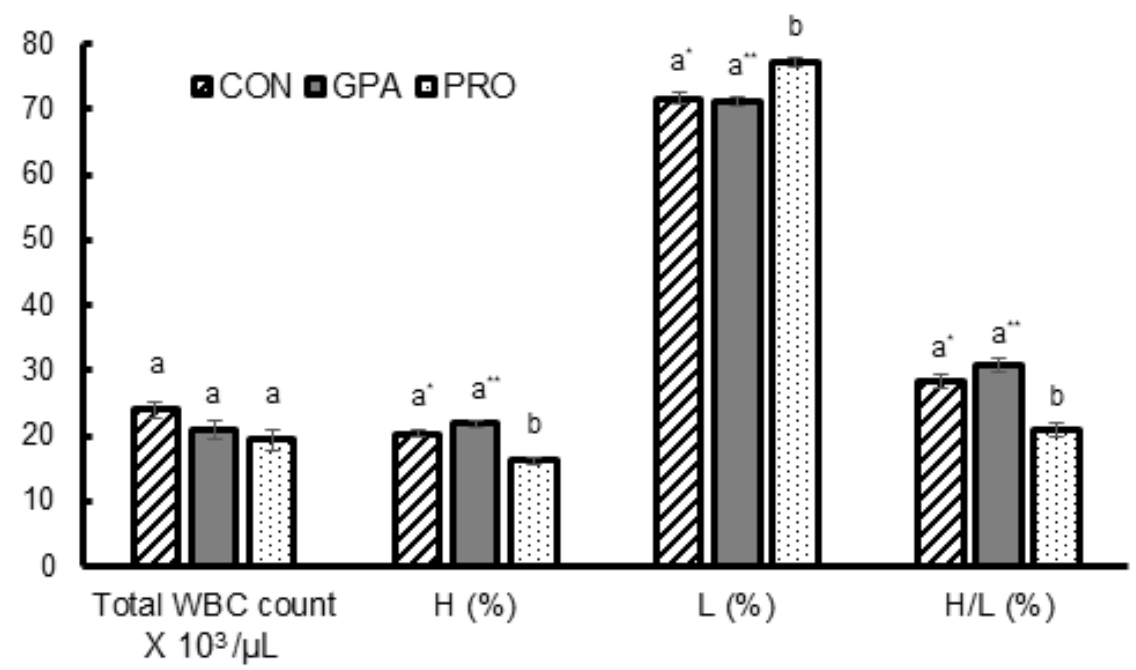

Figure 2

Effects of dietary treatments on total WBC count, heterophile $(H)$, lymphocyte $(L)$, and heterophile/lymphocyte ratio $(\mathrm{H} / \mathrm{L})$ of laying hens at 90 days of the experimental period. 